\title{
PERAN PROFITABILITAS MEMEDIASI PENGARUH LIKUIDITAS DAN STRUKTUR MODAL TERHADAP RETURN SAHAM
}

\author{
Ni Made Cindy Ardina Antriksa ${ }^{1}$ \\ Gede Merta Sudiartha ${ }^{2}$ \\ ${ }^{1}$ Fakultas Ekonomi dan Bisnis Universitas Udayana (Unud), Bali, Indonesia \\ E-mail: cindyardina97@gmail.com
}

\begin{abstract}
ABSTRAK
Penelitian ini bertujuan untuk menganalisis pengaruh likuiditas dan struktur modal terhadap return saham yang dimediasi oleh profitabilitas. Populasi yang digunakan dalam penelitian ini adalah perusahaan tekstil dan garment yang terdaftar di Bursa Efek Indonesia tahun 2015-2017. Metode pengambilan sampel yang digunakan adalah sampling jenuh dengan jumlah sampel sebanyak 14 perusahaan. Pengumpulan data dilakukan melalui observasi non partisipan. Teknik analisis yang digunakan adalah analisis jalur yang dilakukan dengan menggunakan SPSS versi 22. Berdasarkan hasil analisis disimpulkan bahwa likuiditas berpengaruh prositif dan signifikan terhadap profitabilitas, likuiditas berpengaruh negatif dan tidak signifikan terhadap return saham, struktur modal berpengaruh negatif dan signifian terhadap profitabilitas, struktur modal berpengaruh negatif dan signifikan terhadap return saham, profitabilitas berpengaruh negatif dan signifikan terhadap return saham, profitabilitas mampu memediasi pengaruh likuiditas terhadap return saham, dan profitabilitas tidak mampu memediasi pengaruh struktur modal terhadap return saham.
\end{abstract}

Kata kunci: likuiditas, struktur modal, profitabilitas, return saham

\begin{abstract}
This study aims to analyze the effect of liquidity and capital structure on stock returns mediated by profitability. The population used in this study are textile and garment companies listed on the Indonesia Stock Exchange in 2015-2017. The sampling method used was saturated sampling with a total sample of 14 companies. Data collection is done through non-participant observation. The analysis technique used is path analysis carried out using SPSS version 22. Based on the results of the analysis concluded that liquidity has a positive and significant effect on profitability, liquidity has a negative and not significant effect on stock returns, capital structure has a negative and significant effect on profitability, influential capital structure negative and significant effect on stock returns, profitability has a negative and significant effect on stock returns, profitability is able to mediate the effect of liquidity on stock returns, and profitability is not able to mediate the effect of capital structure on stock returns.
\end{abstract}

Keywords: liquidity, capital structure, profitability, stock returns 
Ni Made Cindy Ardina Antriksa,Peran Profotabilitas Memediasi...

\section{PENDAHULUAN}

Era modern seperti saat ini, investasi saham menjadi salah satu pilihan untuk berinvestasi bagi investor lokal dan asing (Anwaar, 2016). Menurut Achaempong (2014) saham adalah sesuatu yang mengacu pada kepemilikan perusahaan dan merupakan klaim atas asset dan pendapatan perusahaan. Investasi saham dapat dilakukan melalui pasar modal. Dalam pasar modal yang efisien terdapat hubungan yang positif antara risiko yang mungkin dihadapi dengan return yang akan didapatkan. Prinsip utama setiap perusahaan adalah ingin memberikan nilai tambah (value added) bagi para shareholder (pemegang saham), maka return saham yang selalu naik akan menjadi salah satu parameter kinerja perusahaan (Widoatmodjo, 2004:14)

Menurut Hartono (2007) return merupakan hasil yang diperoleh dari investasi atau tingkat keuntungan yang dinikmati oleh pemodal atas suatu investasi yang dilakukannya, dengan demikian return saham merupakan tingkat hasil pengembalian yang akan diperoleh investor atas investasinya terhadap saham suatu perusahaan.Proses penentuan harga saham yang akan menentukan return saham di pasar modal secara obyektif dipengaruhi oleh kekuatan permintaan dan penawaran akan saham tersebut. Faktor yang mempengaruhi permintaan dan penawaran saham adalah persepsi investor terhadap saham yang ditawarkan, sedangkan persepsi tersebut muncul dari berbagai macam isu yang berkembang dan juga analisis yang telah dilakukan oleh investor (Nurjanah, 2017).

Industri tekstil dan garmen adalah salah satu sub-sektor industri manufaktur yang terdaftar di Bursa Efek Indonesia. Industri tekstil dan garment mempunyai 
potensi dan peluang yang cukup baik. Industri tekstil dan garmen merupakan perusahaan yang memproduksi kebutuhan pokok yang diperlukan masyarakat. Oleh karena itu, permintaan akan produk insdustri ini akan selalu meningkat seiring dengan pertumbuhan penduduk. Namun demikian, potensi dan peluang perkembangan industri ini bukan tanpa kendala.

Kondisi yang terjadi pada industri tekstil dan garment selama tahun 20152017 ternyata tidak sesuai dengan perkiraan. Return saham pada industri tekstil dan garment mengalami fluktuasi dalam perkembangannya. Seperti yang terlihat pada gambar dibawah ini.

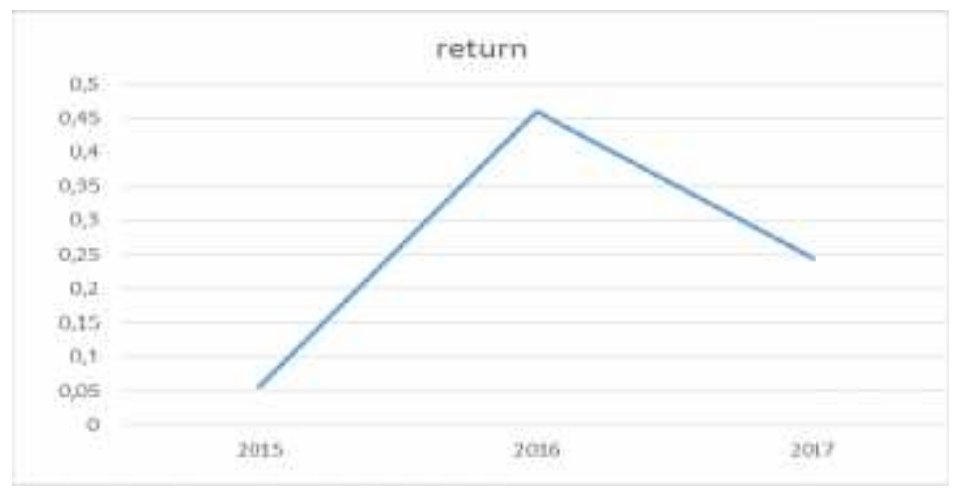

Gambar 1.Perkembangan Return SahamPerusahaan Sektor Tekstil dan Garment di BEI periode 2015-2017

Sumber: www.idx.co.id, 2018

Rasio likuiditas menurut Wiagustini (2010:77) adalah rasio untuk mengukur kemampuan perusahaan untuk memenuhi hutang jangka pendeknya pada saat jatuh tempo. Rasio likuiditas dapat diproksikan menggunakan Current Ratio (CR). Current Ratio adalah rasio yang digunakan untuk menilai kemampuan perusahaan dalam memenuhi kewajibannya yang akan jatuh tempo (Wiagustini, 2010:78).Likuiditas yang tinggi tanpa adanya pemanfaatan nilai yang dimiliki untuk menghasilkan laba bagi perusahaan akan menjadi beban karena bisa 
Ni Made Cindy Ardina Antriksa,Peran Profotabilitas Memediasi...

dikatakan kas tersebut menganggur (idle fund), banyaknya piutang yang tidak tertagih dan rendahnya pinjaman jangka pendek. Hasil yang berbeda akan muncul jika perusahaan merencanakan likuiditas yang tinggi sebagai modal kerja dalam rangka antisipasi terhadap pembayaran hutang jangka pendek maupun bagian dari hutang jangka panjang yang akan harus segera dibayarkan, hal ini akan memberikan manfaat bagi perusahaan berupa peningkatan profitabilitas. Penelitian yang dilakukan oleh Rehmanet al. (2015) dan Candrawati (2017) menyimpulakan bahwa likuiditas berpengaruh positif terhadap profitabilitas, artinya peningkatan pada likuiditas membawa peningkatan pada profitabilitas. Sedangkan penelitian yang dilakukan oleh Sanjaya dkk. (2015) dan Rahmawati (2012) menyimpulkan bahwa likuiditas berpengaruh tidak signifikan terhadap profitabilitas. Sedangkan penelitian yang dilakuka oleh Fitriyani (2013) menemukan bahwa likuiditas berpengaruh negatif tehadap profitabilitas.

Kasmir (2016:128) berpendapat rasio likuditas merupakan suatu kemampuan perusahaan yang digunakan untuk mengukur seberapa likuid kondisi keuangan suatu perusahaan.Perusahaan yang mempunyai likuiditas yang tinggi akan diminati para investor dan akan berimbas pada harga saham dan return saham yang cenderung akan naik karena tingginya permintaan. Karakter investor selalu meminati saham yang cenderung aman dan terus mengalami kenaikan. Penguatan pada likuiditas perusahaan akan menjadi "good news"Fahmi(2014:166). Likuiditas berpengaruh terhadap return saham karena, perusahaan dikatakan likuid saat perusahaan memiliki sumber dana yang ada dalam memenuhi kebutuhan kas jangka pendek, dalam hal ini likuiditas jangka 
pendek perusahaan dipengaruhi oleh arus masuk dan arus keluar serta prospek arus kas untuk kinerja masa depan.Banerjee dan Bandyopadhyay (2016) dan Aga et al. (2013) menyimpulkan pada penelitiannya bahwa likuiditas berpengaruh positif terhadap return saham. Putra (2016) menemukan dalam penelitiannya bahwa likuiditas berpengaruh positif namun tidak signifikan terhadap return saham. Berbeda dari hasl penelitian yang dilakukan oleh Ariyanti (2016) dan Yulia (2016) yang menyimpulkan bahwa likuiditas berpengaruh negatif dan tidak signifikan terhadap return saham.

Menurut Riyanto (2010:282), struktur modal adalah perimbangan atau perbandingan antara jumlah hutang jangka panjang dengan modal sendiri. Porsi modal dan hutang ditentukan oleh perusahaan sesuai dengan posisi keuangan dan kemampuan untuk meningkatkan modal tersebut (Boutilda, 2015). Keputusan pendanaan adalah hal yang sangat penting karena akan mempengaruhi laba bersih dan juga menambah tingkat kemakmuran pemilik. Perusahaan yang baik memperlihatkan pengelolaan struktur modal yang baik juga, karena baik buruknya struktur modal akan mempunyai dampak langsung terhadap posisi finansial perusahaan yang pada akhirnya akan mempengaruhi profitabilitas perusahaan (Violita dan Sulasmiyati, 2017). Penentuan struktur modal optimal memiliki keterkaitan dengan hutang perusahaan, yaitu perusahaan dapat melakukan hutang khususnya hutang jangka panjang. Hutang apabila dikelola dengan baik sebagai modal kerja perusahaan akan memberikan manfaat berupa peningkatan profitabilitas. Hutang dapat diukur dengan debt to equity ratio. Menurut Kasmir (2008:156) debt to equity ratio adalah rasio yang digunakan untuk mengukur 
Ni Made Cindy Ardina Antriksa,Peran Profotabilitas Memediasi...

perbandingan antara total hutang dengan modal sendiri. Penelitian yang dilakukan oleh Gill et al. (2011) menyimpulkan bahwa terdapat pengaruh positif antara struktur modal dan profitabilitas. Violita dan Sulasmiyati (2017) menyimpulkan dalam penelitiannya bahwa struktur modal berpengaruh signifikan terhadap profitabilitas. Sedangkan penelitian yang dilakukan oleh Sudaryo dan Sari (2015) serta Widiyanti dan Elfina (2015) menyimpulkan bawah struktur modal berpengaruh negatif terhadap profitabilitas.

Struktur modal atau proporsi penggunaan hutang atas modal dalam pendanaan perusahaan merupakan salah satu resiko dari sudut pandang investor, hal ini berkaitan dengan sifat investor yang risk averse yaitu cenderung menjauhi resiko (Tandelilin, 2010). Perusahaan dengan struktur modal yang didominasi oleh hutang cenderung dijauhi investor, disebabkan tingginya hutang merupakan beban yang akan mereka tanggung ketika menjadi pemegang saham, selain itu perusahaan dengan hutang yang tinggi juga memiliki resiko likuidasi yang tinggi atau ketidakmampuan dalam melunasi semua kewajibannya. Perusahaan dengan struktur modal yang didominasi oleh hutang tentu memberikan return lebih kecil pada pemegang saham disebabkan besarnya biaya bunga dan hutang yang harus dilunasi, sehingga penggunaaan hutang dalam perusahaan direspon negatif oleh investor. Respon negatif akan berpengaruh pada harga saham dan ikut berdampak pada return saham. Struktur modal dapat dihitung dengan menggunakan ratio debt to equity ratio. Penelitian yang dilakukan oleh Alozzi dan Obiedat (2016) dan Banarjee dan Bandyopadhyay (2015) menyimpulkan bahwa struktur modal berpengaruh negatif terhadap return saham, bertolak belakang dari hasil penelitian 
dari Ibrahim (2017) dan Lindayani (2016) yang menyimpulkan bahwa struktur modal berperngaruh positif terhadap return saham. Profitabilitas adalah rasio yang dapat digunakan untuk menilai kemampuan perusahaan dalam menghasilkan laba atau keuntungan dalam suatu periode tertentu (Kasmir, 2008:114). Salah satu proksi dari rasio profitabilitas adalah Return on Assets (ROA). Return on Assets merupakan rasio keuangan yang digunakan untuk mengukur kemampuan perusahaan dalam menghasilkan laba dari total aktiva yang digunakan. Semakin besar kemampuan perusahaan dalam menghasilkan laba maka akan menarik minat investor untuk berinvestasi pada perusahaan tersebut, hal ini mengakibatkan harga saham dari perusahaan meningkat dan return saham juga akan ikut meningkat. Pernyataan ini didukung oleh penelitian dari Iqbalet al. (2013), Anwaar (2016), dan Alozzi (2016) yang menemukan bahwa ROA berpengaruh positif terhadap return saham. Berbeda dengan penelitian yang dilakukan oleh Zahro (2012) yang menemukan bahwa profitabilitas berpengaruh negatif terhadap return saham.

Tidak konsistennya hasil penemuan terdahulu terhadap pengaruh likuiditas dan struktur modal terhadap return saham menarik untuk dilakukan penelitian kembali dengan tujuan untuk memperjelas penelitian sebelumnya dengan menggunakan rasio proftabilitas sebagai variabel mediasi karena rasio profitabilitas adalah rasio yang dapat digunakan untuk menilai kemampuan perusahaan dalam menghasilkan laba atau keuntungan dalam suatu periode tertentu (Kasmir, 2008:114) Penelitian yang dilakukan Sudarman (2017) menyimpulkan bahwa variabel profitabilitas mampu memediasi pengaruh likuiditas dan struktur modal terhadap return saham. Kurniawan dkk. (2016) 
Ni Made Cindy Ardina Antriksa,Peran Profotabilitas Memediasi...

menyimpulkan dalam penelitiannya bahwa profitabilitas mampu memediasi pengaruh likuiditas terhadap return saham, namun tidak mampu memediasi pengaruh struktur modal terhada return saham. Dalam penelitian yang dilakukan oleh Aditya dan Badjra (2018) menyimpulkan bahwa profitabilitas tidak mampu memediasi pengaruh struktur modal terhadap return saham.

Likuiditas merupakan rasio yang mengukur kemampuan perusahaan dalam memenuhi kewajiban (hutang) jangka pendek (Bringham dan Weston, 2011:129). Likuiditas menunjukkan tingkat ketersediaan modal kerja (aktiva) yang dibutuhkan dalam aktivitas operasional. Modal kerja yang cukup memungkinkan bagi perusahaan untuk beroperasi secara maksimal dan tidak mengalami kesulitan akibat krisis keuangan (Merdiansyah, 2016). Semakin tinggi tingkat likuiditas aktiva lancar atau semakin likuid aktiva lancar yang dimiliki oleh perusahaan maka semakin tinggi profitabilitas yang akan diterima oleh perusahaan. Salah satu proksi dari likuiditas adalah current ratio. Nilai current ratio yang tinggi menandakan perusahaan tersebut dalam keadaan yang baik. Jika perusahaan berencana untuk menggunakan likuiditas sebagai modal kerja dalam rangka menghindari pembayaran hutang jangka pendek atau hutang jangka panjang, maka nilai current ratio yang tinggi akan menjadi nilai positif bagi perusahaan dalam menghasilkan profitabilitas (Sanjaya, 2015). Sesuai dengan penelitian yang dilakukan oleh Rehman (2015), Safdar et al. (2016) dan Akotoet al.(2013) yang menyimpulkan bahwa likuiditas berpengaruh positif dan signifikan terhadap profitabilitas.

$\mathrm{H}_{1}$ : Likuiditas berpengaruh positif dan signifikan terhadap profitabilitas 
Rasio likuiditas adalah rasio yang digunakan untuk menggambarkan kemampuan perusahaan memenuhi kewajiban jangka pendeknya. Rasio likuiditas dapat diukur menggunakan current ratio. Current Ratio mampu menghitung berapa besar tingkat kemampuan suatu perusahaan membayar utang/kewajiban lancarnya dengan aktiva lancar yang dimilikinya. Pemodal akan memperoleh return saham yang tinggi jika kemampuan perusahaan dalam memenuhi utang/kewajiban jangka pendeknya juga tinggi (Munawir, 2011:62). Menurut Parwati dan Sudiartha (2016) semakin tinggi current ratio maka dapat dikatakan kemampuan perusahaan untuk memenuhi kewajiban jangka pendeknya semakin baik, hal ini akan meningkatkan kredibilitas perusahaan dan menarik minat investor untuk berinvestasi sehingga mampu meningkatkan return saham perusahaan. Pernyataan tersebut sejalan dengan penelitian yang dilakukan oleh Banarjee (2016) dan Agaet al. (2013) yang menyimpulkan bahwa likuiditas berpengaruh positif terhadap return saham.

$\mathrm{H}_{2}$ : Likuiditas berpengaruh positif dan signifikan terhadap return saham

Struktur modal merupakan gambaran dari bentuk proporsi finansial perusahaan yaitu antara modal dimiliki bersumber dara hutang jangka panjang dan modal sendiri yang menjadi sumber pembiayaan perusahaan (Fahmi, 2014:184). Debt to equity ratio adalah rasio yang menunjukan perbandingan antara hutang dengan modal sendiri (Husnan dan Pudjiastuti, 2012:72).Hutang dapat dipergunakan perusahaan untuk meningkatkan modal mereka dalam rangka meningkatkan keuntungan (Singapurwoko, 2011). Penggunaan hutang jika dikelola dengan baik dan menghasilkan keuntungan lebih tinggi dibandingkan 
Ni Made Cindy Ardina Antriksa,Peran Profotabilitas Memediasi...

beban hutang yang harus ditanggung perusahaan, maka penggunakaan hutang dapat meningkatkan profitabilitas perusahaan (Purba dan Yadnya, 2015). Pernyataan tersebut didukung oleh penelitian dari Gill et al. (2012) dan Arista dan Topowijono (2017) dimana struktur modal berpengaruh positif dan signifikan terhadap profitabilitas.

$\mathrm{H}_{3}$ : Struktur modal berpengaruh positif dan signifikan terhadap profitabilitas.

Struktur modal adalah perimbangan atau perbandingan antara modal asing dan modal sendiri. Keputusan pendanaan adalah keputusan manajerial yang dapat mempengaruhi mempengaruhi pengembalian dan risiko pemegang saham dan nilai pasar perusahaan (Fredrick dan Muiva, 2015). Semakin besar nilai struktur modal menunjukan kewajiban yang harus dipenuhi perusahaan terhadap pihak luar semakin besar, baik berupa pokok maupun bunga pinjaman, besarnya jumlah hutang perusahaan akan menjadi beban yang harus ditanggung investor ketika menjadi pemegang saham, hal ini akan menyebabkan minat investor menurun untuk melakukan investasi dan berdampak pada penurunan harga saman dan return saham (Parwati dam Sudhiarta, 2016). Seperti penelitian yang dilakukan oleh Alozzi (2016) dan Banarjee (2015) yang menyimpulkan bahwa struktur modal memiliki pengaruh yang negatif dan signifikan terhadap return saham.

$\mathrm{H}_{4}$ : Struktur modal berpengaruh negatif dan signifikan terhadap return saham.

Rasio profitabilitas adalah rasio yang digunakan untuk menilai efektivitas manajemen secara menyeluruh yang ditunjukan oleh besar kecilnya tingkat keuntungan yang didapatkan dalam hubungannya dengan penjualan ataupun 
investasi (Sartono, 2000:64). Return on Assets adalah proksi dari rasio profitabilitas yang digunakan dalam penelitian ini. Semaki tinggi return on assets, maka semakin tinggi keuntungan yang dihasilkan oleh perusahaan dari total aktiva yang dimiliki. Kemampuan perusahaan dalam menghasilkan laba yang tinggi akan menarik investor untuk berinvestasi maka permintaan saham akan meningkat yang akan berdampak pada peningkatan harga saham dan diikuti dengan return saham yang meningkat. Iqbal et al. (2013), Anwaar (2016), dan Alozzi (2016) yang menemukan bahwa profitabilitas berpengaruh positifdan signifikan terhadap return saham.

$\mathrm{H}_{5}$ : Profitabilitas berpengaruh positif dan signifikan terhadap return saham

Likuiditas dalam suatu perusahaan mewakili jumlah investasi dalam aktiva lancar dan produktivitas aktiva lancar tesebut dalam meningkatkan profitabilitas. Jika perusahaan melakukan investasi terhadap aktiva lancar yang tidak produktif dapat menyebabkan penuruan profitabilitas atau kemampuan perusahaan dalam menghasilkan laba (Varghese dan Dhote, 2014). Sebaliknya jika perusahaan melakukan investasi pada aktiva lancar yang produktif maka profitabilitas perusahaan akan meningkat. Seperti penelitian yang dilakukan oleh Rehman (2015), Safdaret al. (2016) menyimpulkan bahwa likuiditas berpengaruh positif dan signifikan terhadap profitabilitas. Profitabilitas yang tinggi berarti laba yang dihasilkan perusahaan semakin besar. Pertumbuhan profitabilitas adalah salah satu indikator yang digunakan untuk menilai prospek perusahaan dimasa depan. Apabila prospek perusahaan baik, investor akan tertarik untuk melakukan investasi, maka harga saham akan meningkat dan akan berdampak pada 
Ni Made Cindy Ardina Antriksa,Peran Profotabilitas Memediasi...

peningkatan return saham (Nandani dan Sudjarni, 2017). Penelitian yang dilakukan oleh Iqbalet al. (2013), Anwaar (2016) menyimpulkan profitabiltas berpengaruh positif dan signifikan terhadap return saham. Penelitian yag dilakukan oleh Sudarman (2017) dan Kurniawan (2016) menyimpulkan bahwa profitabilitas mampu memediasi pengaruh likuiditas terhadap return saham.

$\mathrm{H}_{6}$ : Profitabilitas mampu memediasi pengaruh likuiditas terhadap return saham.

Sudana (2011:143) berpendapat bahwa struktur modal (capital structure) berkaitan dengan pembelanjaan jangka panjang suatu perusahaan yang diukur dengan perbandingan hutang jangka panjang dengan modal sendiri. Struktur modal akan dialokasikan untuk pembelanjaan investasi pada aktiva perusahaan .Struktur modal perusahaan dapat berdampak pada profitabilitas. Struktur modal bila tidak dikelola dengan baik akan mengakibatkan penggunaan hutang tidak dapat mencapai target penjualan dan laba perusahaan menurun, maka akan menurunkan profitabilitas perusahaan. Sedangkan struktur modal akan berdampak positif terhadap profitabilitas apabila penggunaan hutang dikelola dengan baik sehingga dapat mencapai target penjualan dan laba perusahaan meningkat (Arista dan Topowijono, 2017). Peneltian yang dilakukan oleh Gillet al. (2012) dan Arista dan Topowijono (2017) menemukan bahwa struktur modal berpengaruh positif terhadap profitabilitas. Profitabilitas merupakan kemampuan perusahaan untuk menghasilkan laba selama periode tertentu (Munawir, 2004:33). Jika perusahaan dapat menghasilkan laba yang tinggi, maka permintaan akan saham meningkat dan akan berdampak pada meningkatnya harga saham perusahaan, harga saham yang semakin meningkat maka return saham juga akan 
meningkat (Mariana dkk., 2016). Penelitian yang dilakukan oleh Sudarman (2017) menyimpulkan bahwa proftabilitas mampu memediasi pengaruh struktur modal terhadap return saham.

$\mathrm{H}_{7}$ : Profitabilitas mampu memediasi pengaruh struktur modal terhadap return saham.

\section{METODE PENELITIAN}

Ruang lingkup wilayah penelitian ini adalah perusahaan pada perusahaan tekstil dan garment yang terdaftar di Bursa Efek Indonesia (BEI) periode 20152017 dengan mengakses website www.idx.co.id. Obyek penelitian ini adalah peran profitabilitas yang di proksikan dengan return on assets (ROA) dalam memediasi likuiditas yang di proksikan dengan current ratio (CR) dengan struktur modal yang di proksikan dengan debt to equity ratio (DER) terhadap return saham perusahaan tekstil dan garment yang terdaftar di Bursa Efek Indonesia (BEI) periode 2015-2017. Variabel endogen dalam penelitian ini adalah return saham. Variabel enksogen dalam penelitian ini adalah Current Assets (CR) dan Debt to Equity Ratio (DER). Variabel intervening atau mediasi dalam penelitian ini adalaj Return on Assets (ROA).

Formula dari return saham adalah sebagai berikut (Hartono, 2015:265):

$K=\frac{\mathrm{r}-\mathrm{P}-1}{\mathrm{P}-1}$

Keterangan:

Rt $=$ Return saham periode $\mathrm{t}$

$\mathrm{Pt}=$ closing price harga saham tahun sekarang

Pt-1 = closing price harga saham periode lalu 
Ni Made Cindy Ardina Antriksa,Peran Profotabilitas Memediasi...

Formula dari current ratio (CR) adalah sebagai berikut (Wiagustini, 2014:87):

C R $\quad(C)=\frac{a}{p} \quad u$

Formula dari debt to equity ratio adalah sebagai berikut:

$D \quad t_{1} E \quad R \quad=\frac{t_{1}}{n u}$

Formula dari return on assets adalah (Wiagustini, 2014:90):

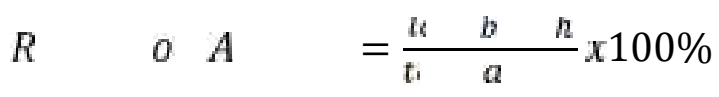

Populasi yang digunakan dalam penelitian ini adalah perusahaan tekstil dan garment yang terdaftar di Bursa Efek Indonesia (BEI) pada periode 2015-2017 dengan jumlah 14 perusahaan. Metode penentuan sampel yang digunakan dalam penelitian ini adalah sampling jenuh, yaitu teknik penentuan sampel bila semua anggota populasi digunakan sebagai sampel.

Metode pengumpulan data yang digunakan dalam penelitian ini adalah pengumpulan data observasi non partisipan dimana peneiliti tidak terlibat dan hanya sebagai pengamat yang bersifat independen. Data dalam penelitian ini yaitu data keuangan pada perushaan tekstil dan garmen yang terdaftar di Bursa Efek Indonesia (BEI) periode 2015-2017 yang dipublikasikan pada website www.idx.co.id

Teknik analisis data yang digunakan dalam penelitian ini adalah Teknik analisis jalur. 
Persamaan Sub-struktural 1

$$
\mathrm{Y} 1=\mathrm{x} 1+\mathrm{x} 2+\mathrm{e} 1
$$

Persamaan Sub-struktural 2

$$
\mathrm{Y} 2=\mathrm{x} 1+\mathrm{x} 2+\mathrm{y} 1+\mathrm{e} 2
$$

Keterangan:

$$
\begin{aligned}
& \text { Y1=Profitabilitas } \\
& \text { Y2=Return Saham } \\
& \mathrm{X} 1=\text { Likuiditas } \\
& \mathrm{X} 2=\text { Struktur Modal } \\
& \text { e1= Error of term atau variabel pengganggu pada variabel profitabiltas } \\
& \text { e2= Error } \text { of term atau variabel pengganggu pada variabel return saham }
\end{aligned}
$$

Uji sobel merupakan alat analisi untuk menguji signifikansi dari hubungan tidak langsung antara variable eksogen dengan variable endogen yang dimediasi oleh variabel intervening atau mediasi. Uji sobel dirumuskan dengan persamaan berikut dan dapat dihitung dengan menggunakan aplikasi Microsoft Excel 2010.

Uji sobel dirumuskan sebagai berikut:

$$
z=\frac{a}{\sqrt{u^{2} s_{L}^{2}+b^{2} s_{u}^{2}+s_{u}^{2} \Delta_{L}^{2}}} \ldots \ldots \ldots \ldots \ldots . .(7)
$$

Keterangan:

$\mathrm{Z}=$ nilai kalkulasi sobel

$\mathrm{a}=$ koefisien regresi dari variabel eksogen $(\mathrm{x})$ terhadap variabel moderator (Y1). 
$\mathrm{Sa}=$ varian dari $\mathrm{a}$

$\mathrm{b}=$ koefisien regresi dari variabel moderator (Y1) terhadap variabel endogen (Y2)

$\mathrm{Sb}=$ varian dari $\mathrm{b}$

\section{HASIL DAN PEMBAHASAN}

Analisis data deskriptif dilakukan untuk memberikan gambaran atau deskripsi mengenai variabel yang diteliti dimana terdiri dari likuiditas (X1), struktur modal (X2), profitabilitas (Y1), dan return saham (Y2).

\section{Tabel 1.}

Hasil Statistik Deskriptif Sampel Penelitian

\begin{tabular}{llllll}
\hline & N & Minimum & Maximum & Mean & $\begin{array}{l}\text { Std. } \\
\text { Deviation }\end{array}$ \\
\hline Return Saham & 42 & $-0,49$ & 0,95 & 0,1286 & 0,29961 \\
Profitabilitas & 42 & $-8,30$ & 6,27 & $-0,5569$ & 2,08872 \\
Likuiditas & 42 & 59,62 & 364,18 & 181,2098 & 68,98665 \\
Struktur Modal & 42 & 0,11 & 3,15 & 1,1705 & 0,60215 \\
\hline
\end{tabular}

Sumber: Data Diolah, 2018

Hasil statistik deskriptif pada tabel diatas menunjukkan bahwa nilai minimum Return Saham sebesar $-0,49$ persen dan nilai maksimum sebesar 0,95 persen. Hal ini menunjukkan bahwa besarnya return saham pada sampel penelitian ini berkisar antara $-0,49$ persen sampai 0,95 persen dengan rata-rata 0,1286 pada standar deviasi sebesar 0,29961. Nilai return saham tertinggi pada Polychem Indonesia Tbk tahun 2017 yaitu 0,95 persen, sedangkan nilai return saham terendah pada Sunson Textile Manufacturor Tbk tahun 2015 yaitu -0,49 persen.

Hasil statistik deskriptif pada tabel diatas menunjukkan bahwa nilai minimum profitabilitas sebesar $-8,30$ dan nilai maksimum sebesar 6,27 . Hal ini menunjukkan bahwa besarnya profitabilitas pada sampel penelitaian ini berkisar - 
8,30 sampai 6,27 dengan rata-rata (mean) sebesar -0,5569 pada standar deviasi sebesar 2,08872. Nilai profitabilitas tertinggi pada Sri Rejeki Isman Tbk tahun 2016 yaitu 6,27, sedangkan nilai profitabilitas terendah pada Panasia Indo Resources Tbk tahun 2016 yaitu $-8,30$.

Hasil statistik deskriptif pada tabel di atas menunjukkan bahwa nilai minimum likuiditas sebesar 59,62 dan nilai maksimum sebesar 364,18 . Hal ini menunjukkan bahwa besarnya likuiditas pada sampel penelitian ini berkisr 59,62 sampai 364,18 dengan rata-rata (mean) sebesar 181,2098 pada standar deviasi sebesar 68,98665 . Nilai likuiditas tertinggi pada Tifico Fiber Indonesia tahun 2017 yaitu 364,18, sedangkan nilai likuiditas terendah pada Nusantara Inti Corpora Tbk tahun 2015 yaitu 59,62.

Hasil statistik deskriptif pada tabel di atas menunjukkan bahwan nilai minimum struktur modal sebesar 0,11 dan nilai maksimum sebesar 3,15 . Hal ini menunjukkan bahwa besarnya struktur modal pada sampel penelitian ini berkisar 0,11 sampai 3,15 dengan rata-rata (mean) 1,1705 pada stadar deviasi sebesar 0,60215. Nilai struktur modal tertinggi pada Ever Shine Tex Tbk tahun 2017 yaitu 3,15, sedangkan nilai struktur modal terendah pada Tifico Fiber Indonesia tahun 2016 yaitu 0,11 .

Data yang telah diolah dan dihitung akan menunjukkan hasil analisis seperti Tabel 2 dan Tabel 3.

Tabel 2. Hasil Analisis Jalur Persamaan Regresi 1

\begin{tabular}{lccccc}
\hline Model & $\begin{array}{c}\text { Unstandardized } \\
\text { Coefficients } \\
\text { B }\end{array}$ & Std. Error & $\begin{array}{c}\text { Standardized } \\
\text { Coefficients } \\
\text { Beta }\end{array}$ & T & Sig. \\
\hline 1 (Constant) & $-1,227$ & 1,199 & & $-1,023$ & 0,313
\end{tabular}




\begin{tabular}{lccccc}
\hline CR & 0,011 & 0,004 & 0,349 & 2,392 & 0,022 \\
DER & $-1,062$ & 0,506 & $-0,306$ & $-2,100$ & 0,042 \\
& & & Sig F: & \\
R12: 0,299 & & F Statistik: & & 0,001 & \\
& & 8,321 & & & \\
\hline
\end{tabular}

Sumber: Data diolah, 2018

Hasil analisis jalur substruktur 1 telah disajikan pada Tabel 3 maka persamaan strukturalya adalah sebagai berikut:

$$
\begin{gathered}
\mathrm{Y} 1=\mathrm{x} 1+\mathrm{x} 2+\mathrm{e} 1 \\
\mathrm{Y} 1=0,349 \mathrm{x} 1+(-0,306) \times 2+\mathrm{e} 1
\end{gathered}
$$

Tabel 3.

\begin{tabular}{|c|c|c|c|c|c|}
\hline \multirow[t]{2}{*}{ Model } & $\begin{array}{l}\text { Unstandardized } \\
\text { Coefficients }\end{array}$ & & $\begin{array}{l}\text { Standardized } \\
\text { Coefficients }\end{array}$ & \multirow[t]{2}{*}{$\mathrm{T}$} & \multirow[t]{2}{*}{ Sig. } \\
\hline & $\mathrm{B}$ & Std. Error & Beta & & \\
\hline 1 (Constant) & 0,413 & 0,187 & & 2,209 & 0,033 \\
\hline $\mathrm{CR}$ & 0,000 & 0,001 & $-0,027$ & $-0,161$ & 0,874 \\
\hline DER & $-0,248$ & 0,082 & $-0,499$ & $-3,030$ & 0,004 \\
\hline ROA & $-0,050$ & 0,025 & $-0,349$ & $-2,034$ & 0,049 \\
\hline R22: 0,216 & & $\begin{array}{c}\text { F statistik: } \\
3,484\end{array}$ & & $\begin{array}{l}\text { Sig F: } \\
0,025\end{array}$ & \\
\hline
\end{tabular}

Hasil Analisis Jalur Persamaan Regresi 2

Sumber: Data diolah, 2018

Hasil analisis jalur substruktur 2 telah disajikan pada Tabel 4, maka persamaan strukturalnya adalah sebagai berikut:

$$
\begin{gathered}
\mathrm{Y} 2=\text { py } 2 \times 1+\text { py } 2 \times 2+\text { py } 2 y 1+e 2 \\
\mathrm{Y} 2=(-0,027) \mathrm{x} 1+(-0,499) \times 2+(-0,349) \mathrm{y} 1+\mathrm{e} 2
\end{gathered}
$$

Hasil pengujian pada Tabel 2 diperoleh nilai koefisien signifikan $0,001 \leq$ 0,05. Hasil tersebut menunjukkan bahwa CR, dan DER berpengaruh secara simultan terhadap ROA.

Hasil pengujian pada Tabel 3 diperoleh nilai koefisien signifikan 0,025 $\leq$ 0,05. Hasil tersebut menunjukan bahwa CR, DER dan ROA berpengaruh secara simultan dan signifikan terhadap return saham. 
Hipotesis dalam penelitian ini likuiditas berpengaruh positif dan signifikan terhadap profitabilitas. Berdasarkan hasil pengujian pengraruh likuiditas (X1) dan profitabilitas (Y1) yang ditunjukkan pada Tabel 2, diketahui bahwa tingkat signifikansi t uji sebesar 0,022 yang menunjukkan angka lebih kecil daripada taraf nyata dalam penelitian ini yaitu $\alpha=0,05$ dengan nilai koefisien beta 0,349 . Hal ini menunjukkan bahwa likuiditas berpengaruh positif dan signifikan terhadap profitabilitas. Hasil ini menerima $\mathrm{H}_{1}$ yakni likuiditas berpengaruh positif dan signifikan terhadap profitabilitas.

Hasil penelitian ini mendukung hasil penelitian sebelumnya. Likuiditas dalam penelitian ini diproksikan dengan current ratio. Nilai current ratio yang tinggi menandakan perusahaan tersebut dalam keadaan yang baik. Jika perusahaan berencana untuk menggunakan likuiditas sebagai modal kerja dalam rangka menghindari pembayaran hutang jangka pendek atau hutang jangka panjang, maka nilai current ratio yang tinggi akan menjadi nilai positif bagi perusahaan dalam menghasilkan profitabilitas (Sanjaya, 2015).

Hipotesis dalam penelitian ini likuiditas berpengaruh positif dan signifikan terhadap return saham. Berdasarkan hasil pengujian pengaruh likuiditas (X1) terhadap return saham (Y2) yang ditunjukkan pada Tabel 3, diketahui bahwa tingkat signifikansi t uji sebesar 0,874 yang menunjukkan angka lebih besar dari taraf nyata dalam penelitian ini yaitu $\alpha=0,05$ dengan nilai koefisien beta sebesar -0,027. Hal ini menunjukkan bahwa likuiditas berpengaruh negatif dan tidak signifikan pada return saham. Hasil ini menolak $\mathrm{H}_{2}$ yakni likuiditas berpengaruh positif dan signifikan terhadap return saham. 
Ni Made Cindy Ardina Antriksa,Peran Profotabilitas Memediasi...

Hasil penelitian ini bertentangan dengan penelitian yang dilakukan oleh Banarjee (2016) dan Aga et al. (2013) yang menyimpulkan bahwa likuiditas berpengaruh positif terhadap return saham. Hasil penelitian ini menunjukkan bahwa likuiditas berpengaruh negatif dan tidak signifikan terhadap return saham yang berarti likuiditas tidak memiliki pengaruh terhadap return saham. Likuiditas yang tinggi menunjukkan bahwa perusahaan memiliki jumlah aktiva lancar yang besar, jumlah aktiva lancar yang tinggi apabila tidak dikelola dengan baik akan mengakibatkan banyak aktiva lancar yang menganggur dan penggunaan aktiva lancar kurang maksimal untuk meningkatkan keuntungan perusahaan, sehingga investor tidak terlalu memperhatikan tingkat likuiditas dalam membuat keputusan investasi. Hasil penelitian ini sejalan dengan penelitian yang dilakukan oleh Ariyanti (2016), Yulia (2016) dan Sugiarti dkk. (2015) yang menyimpulkan bahwa likuiditas berpengaruh negatif dan tidak signifikan terhadap return saham.

Hipotesis dalam penelitian ini struktur modal berpengaruh positif dan signifikan terhadap profitabilitas. Berdasarkan hasil pengujian pengaruh struktur modal (X2) terhadap profitabilitas (Y1) yang ditunjukkan pada Tabel 2, diketahui bahwa tingkat signifikansi t uji sebesar 0,042 yang menunjukkan angka lebih kecil daripada taraf nyata dalam penelitian ini yaitu $\alpha=0,05$ dengan nilai koefisien beta struktur modal sebesar -0,306. Hal ini menunjukkan bahwa struktur modal berpengaruh negatif dan signifikan terhadap profitabilitas. Hasil ini menolak $\mathrm{H}_{3}$ yakni struktur modal berpengaruh positif dan signfikan terhadap profitabilitas.

Hasil penelitian ini bertentangan dengan penelitian yang dilakukan oleh Gillet al. (2012) dan Arista dan Topowijono (2017) dimana struktur modal 
berpengaruh positif terhadap profitabilitas. Hasil ini berbeda karena peningkatan total hutang lebih besar dibandingkan peningkatan total modal sendiri sehingga dapat meningkatkan beban hutang yang menyebabkan profitabilitas menurun. Semakin tinggi DER menunjukkan komposisi total hutang semakin besar dibanding dengan total modal sendiri, sehingga berdampak semakin besar beban perusahaan terhadap pihak luar (kreditur), apabila hal tersebut terjadi, maka akan berdampak pada menurunnya perolehan profitabilitas perusahaan. Hal ini didukung oleh teori trade-off dimana penggunaan utang melampaui batas optimal, karena beban bunga lebih besar daripada manfaat yang diberikan dari pengunaan hutang sehingga keuntungan perusahaan menjadi menurun. Penelitian ini sejalan dengan penelitian yang dilakukan oleh Sudaryo dan Sari (2013) serta Widiyanti dan Elfina (2015) menyimpulkan bawah struktur modal berpengaruh negatif dan signifikan terhadap profitabilitas.

Hipotesis dalam penelitian ini struktur modal berpengaruh negatif dan signifikan terhadap return saham. Berdasarkan hasil pengujian pengaruh struktur modal (X2) terhadap return saham (Y2) yang ditunjukkan pada Tabel 3, diketahui bahwa tingkat signifikansi t uji sebesar 0,004 yang menunjukkan angka lebih kecil daripad taraf nyata dalam penelitian ini yaitu $\alpha=0,05$ dengan nilai koefisien beta sebesar -0,499. Hal ini menunjukkan bahwa struktur modal berpengaruh negatif dan signifikan terhadap return saham. Hasil ini menerima $\mathrm{H}_{4}$ yakni struktur modal berpengaruh positif dan signifikan terhadap return saham.Hasil penelitian ini sejalan dengan penelitian yang dilakukan oleh Alozzi (2016) dan Banarjee (2015) 
Ni Made Cindy Ardina Antriksa,Peran Profotabilitas Memediasi...

yang menyimpulkan bahwa struktur modal memiliki pengaruh yang negatif dan signifikan terhadap return saham.

Hipotesis dalam penelitian ini profitabilitas berpengaruh positif dan signifikan terhadap return saham. Berdasarkan hasil pengujian pengaruh profitabilitas (Y1) pada return saham (Y2) yang ditunjukkan pada Tabel 3, diketahui bahwa tingkat signifikansi t uji sebesar 0,049 yang menunjukkan angka lebih kecil daripada taraf nyata dalam penelitian ini yaitu $\alpha=0,05$ dengan nilai koefisian beta $-0,349$. Hal ini menunjukkan bahwa profitabilitas berpengaruh negatif dan signifikan terhadap return saham. Hasil ini menolak $\mathrm{H}_{5}$ yakni profitabilitas berpengaruh positif dan signifikan terhadap return saham.

Hasil penelitian ini bertentangan dengan hasil penelitian sebelumnya yang dilakukan oleh Iqbalet al. (2013), Anwaar (2016), dan Alozzi (2016) yang menemukan bahwa profitabilitas yang diproksikan dengan return on asset berpengaruh positif dan signifikan terhadap return saham. Hasil ini berbeda karena return on asset cenderung hanya memperhatikan laba namun tidak memperhitungkan biaya modal yang terjadi pada perusahaan. Hal ini mengakibatkan tingkat laba yang diperoleh dengan menggunakan rasio return on asset sering kurang akurat. Penelitian ini sejalan dengan penelitian yang dilakukan oleh Zahro (2012) yang menemukan bahwa profitabilitas berpengaruh negatif terhadap return saham.

Perhitungan pengaruh antar variabel ditunjukan pada Tabel 4.14 dan Tabel 4 berikut.

Tabel 4. 
Pengaruh Langsung, Pengaruh Tidak Langsung serta Pengaruh Total Likuiditas $\left(\mathbf{X}_{1}\right)$, Profitabilitas $\left(\mathbf{Y}_{1}\right)$ dan Return Saham $\left(\mathbf{Y}_{2}\right)$

\begin{tabular}{lrcc}
\hline $\begin{array}{l}\text { Pengaruh } \\
\text { Variabel }\end{array}$ & $\begin{array}{l}\text { Pengaruh } \\
\text { Langsung }\end{array}$ & $\begin{array}{l}\text { Pengaruh tidak langsung melalui } \\
\text { Profitabilitas } \\
\mathbf{Y}_{\mathbf{1}}=(\text { Px1y1 x Py1y2 })\end{array}$ & $\begin{array}{l}\text { Pengaruh } \\
\text { Total }\end{array}$ \\
\hline X1 $\rightarrow$ Y1 & 0,349 & - & 0,349 \\
X1 $\rightarrow$ Y2 & $-0,027$ & $-0,122$ & $-0,149$ \\
Y1 $\rightarrow$ Y2 & $-0,349$ & - & $-0,349$ \\
\hline
\end{tabular}

Sumber: Data diolah, 2018

Hasil pada Tabel 4 menunjukkan pengaruh langsung likuiditas terhadap return saham sebesar $-0,027$, sedangkan pengaruh tidak langsung yang dimediasi oleh profitabilitas menunjukkan nilai koefisien beta sebesar $-0,122$. Hasil tersebut membuktikan bahwa profitabilitas mampu memediasi pengaruh likuiditas terhadap return saham dengan pengaruh total yang diperoleh sebesar $-0,149$.

Tabel 5.

\section{Pengaruh Langsung, Pengaruh Tidak Langsung serta Pengaruh Total Struktur Modal $\left(\mathbf{X}_{2}\right)$, Profitabilitas $\left(\mathbf{Y}_{1}\right)$ dan Return Saham $\left(\mathbf{Y}_{2}\right)$}

\begin{tabular}{lccc}
\hline $\begin{array}{l}\text { Pengaruh } \\
\text { Variabel }\end{array}$ & $\begin{array}{l}\text { Pengaruh } \\
\text { Langsung }\end{array}$ & $\begin{array}{l}\text { Pengaruh tidak langsung melalui } \\
\text { Profitabilitas } \\
\mathbf{Y}_{\mathbf{1}}=(\mathbf{P x 1} 1 \mathbf{1} \text { x Py1 } \mathbf{2})\end{array}$ & $\begin{array}{l}\text { Pengaruh } \\
\text { Total }\end{array}$ \\
\hline $\mathrm{X} 2 \rightarrow$ Y1 & $-0,306$ & - & $-0,306$ \\
$\mathrm{X} 2 \rightarrow$ Y2 & $-0,499$ & 0,106 & $-0,393$ \\
Y1 $\rightarrow$ Y2 & $-0,349$ & - & $-0,349$ \\
\hline Sumber: Data diolah, 2018 & &
\end{tabular}

Hasil pada Tabel 5 menunjukkan pengaruh langsung struktur modal terhadap return saham sebesar -0,499, sedangkan pengaruh tidak langsung yang dimediasi oleh profitabilitas menunjukkan nilai koefisien beta sebesar 0,106. Hasil tersebut membuktikan bahwa profitabilitas tidak mampu memediasi pengaruh struktur modal terhadap return saham dengan pengaruh total yang diperoleh sebesar $-0,393$.

Uji sobel dilakukan untuk menguji pengaruh tidak langsung variabel likuiditas (X1) dan variabel struktur modal (X2) terhadap return saham (Y2) melalui profitabilitas (Y1). Uji sobel dihitung dengan menggunakan aplikasi 
Microsoft Excel 2010. Tahapan dalam pengujian pengaruh tidak langsung dengan uji sobel yaitu sebagai berikut. $=0,05$.

$$
\begin{aligned}
& Z=\frac{u_{1} b}{\sqrt{u_{1}^{2} \Delta_{L}^{2}+b^{2} S{ }_{1}^{2}+S{ }_{1}^{2} s_{L}^{2}}} \\
& Z=\frac{(0,0 \quad(-0,0 \quad)}{\sqrt{(0,0 \quad)^{2}(0,0 Z)^{2}+(-0,0 \quad)^{2}(0,0 \quad)^{2}+(0,0 \quad)^{2}(0,0 \quad)^{2}}} \\
& z=\frac{-0,0}{\sqrt{0,06 \quad+0,06 \quad+0,0 i}} \\
& z=\frac{-0,00055}{0,00036} \\
& \mathrm{z}=-1,55
\end{aligned}
$$

Berdasarkan hasil uji sobel dalam penelitian ini menunjukkan bahwa hasil tabulasi $Z=-1,55<1,96$. Hasil tersebut memiliki arti bahwa profitabilitas tidak memediasi pengaruh likuiditas terhadap return saham.

$$
\begin{aligned}
& Z=\frac{u_{2} b}{\sqrt{u_{2}^{2} \Delta_{E}^{2}+b^{2} S 2^{2}+S{ }_{2}^{2} \Delta_{L}^{2}}} \\
& Z=\frac{(-1,0)(-0,0 \quad)}{\sqrt{(-1,0 \quad)^{2}(0,0 \quad)^{2}+(-0,0 \quad)^{2}(0,5 \quad)^{2}+(0,5 \quad)^{2}(0,0 \quad)^{2}}} \\
& z=\frac{0,0}{\sqrt{0,0 \quad+0,0 \quad 9+0,06}} \\
& z=\frac{0,0}{0,0} \\
& \mathrm{z}=1,37
\end{aligned}
$$

Berdasarkan hasil uji sobel dalam penelitian ini menunjukkan bahwa hasil tabulasi $\mathrm{Z}=1,37<1,96$. Hasil tersebut memiliki arti bahwa profitabilitas tidak memediasi pengaruh struktur modal terhadap return saham.

Peran profitabilitas memediasi pengaruh likuiditas terhadap return saham telah diuji dalam penelitian ini. Hasil uji pengaruh likuiditas terhadap return saham semula bernilai $-0,027$, kemudian setelah adanya profitabilitas sebagai variabel mediasi, nilai pada pengaruh likuiditas terhadap return saham meningkat 
menjadi sebesar -0,149. Uji sobel yang telah dihitung memperoleh nilai koefisien z sebesar $-1,55<1,96$.

Berdasarkan hasil analisis jalur, dapat disimpulkan bahwa profitablitas mampu memediasi pegaruh likuiditas terhadap return saham karena likuiditas memiliki pengaruh yang tidak signifikan terhadap return saham, sedangkan likuiditas terhadap profitabilitas dan profitabilitas terhadap return saham memiliki pengaruh yang signifikan terhadap return saham oleh karena itu profitabilitas mampu memediasi pengaruh likuiditas terhadap return saham. Hasil penelitian ini didukung oleh penelitian yang dilakukan oleh Sudarman (2017) dan Kurniawandkk. (2016) yang menyimpulkan bahwa profitabilitas mampu memediasi pengaruh profitabilitas terhadap return saham.

Peran profitabilitas memediasi pengaruh struktur modal terhadap return saham telah diuji dalam penelitian ini. Hasil uji pengaruh struktur modal terhadap return saham semula bernilai $-0,499$, kemudian setelah adanya profitabilitas sebagai variabel mediasi, nilai pada pengaruh struktur modal terhadap nilai saham turun menjadi sebesar $-0,393$. Uji sobel yang telah dihitung memperoleh nilai keofisien $\mathrm{z}$ sebesar $1,37<1,96$, bahwa profitabilitas tidak mampu memediasi pengaruh struktur modal terhadap return saham. Hal ini bermakna dalam melakukan pengambilan keputusan berinvestasi investor lebih melihat perkembangan penggunaan hutang perusahaan dibandingkan dengan profitabilitas perusahaan. Investor dalam mengambil keputusan untuk berinvestasi tidak melihat dari satu rasio profitabilitas, tetapi menggunakan rasio profitabilitas lainnya. Hasil penelitain ini sejalan dengan penelitian yang dilakukan oleh 
Ni Made Cindy Ardina Antriksa,Peran Profotabilitas Memediasi...

Kurniawan dkk. (2016) serta Aditya dan Badjra (2018) yang menyimpulkan bahwa profitabilitas tidak mampu memediasi pengaruh struktur modal terhadap return saham.

\section{SIMPULAN}

Likuiditas berpengaruh positif dan signifikan terhadap profitabilitas. Nilai likuiditas yang tinggi akan menjadi nilai positif bagi perusahaan dalam menghasilkan profitabilitas.Likuiditas berpengaruh negatif dan tidak signifikan terhadap return saham. Likuiditas yang tinggi apabila tidak dikelola dengan baik akan menyebabkan banyak aktiva lancar menganggur dan tidak dioptimalkan oleh perusahaan, yang berakibat pada menurunnya minat investor dalam menanamkan modalnya.Struktur modal berpengaruh negatif dan signifikan terhadap profitabilitas. peningkatan total hutang lebih besar dibandingkan peningkatan total modal sehingga dapat meningkatkan beban hutang yang menyebabkan profitabilitas menurun.Struktur Modal berpengaruh negatif dan signifikan terhadap return saham. Semakin besar struktur modal menunjukan kewajiban yang harus dipenuhi perusahaan terhadap pihak luar semakin besar, baik berupa pokok maupun bunga pinjaman. Hal ini menyebabkan kinerja perusahaan semakin buruk dan berdampak pada penurunan harga saham di pasar modal.Profitabilitas berpengaruh negatif dan signifikan terhadap return saham. Profitabilitas yang rendah namun return saham perusahaan meningkat dikarenakan return on asset cenderung hanya memperhatikan laba namun tidak memperhitungkan biaya modal yang terjadi pada perusahaan.Profitabilitas mampu memediasi pengaruh likuiditas terhadap return saham. Adanya variabel tambahan profitabilitas 
mempengaruhi likuiditas dalam meingkatkan return saham.Profitabilitas tidak mampu memediasi pengaruh struktur modal terhadap return saham. Adanya variabel tambahan profitabilitas tidak mempengaruhi struktur modal dalam meningkatkan return saham.

Saran untuk investor, berdasarkan penelitian ini diharapkan dapat memberikan infomasi yang menjadi bahan pertimbangan dalam menentukan dan memutuskan investasi yang dilakukan.Bagi peneliti selanjutnya yang ingin meneliti mengenai return saham, tambahkan variabel lain sebagai variabel bebas, dan gunakan variabel lain sebagai variabel mediasi sehingga didapatkan indikator lain yang memiliki hubungan dengan return saham.

\section{REFERENSI}

Achaempong, P; Agalega, E; Shibu, A. K. (2014). The Effect of Financial Leverage and Market Size on Stock Returns on The Ghana Stock Exchange: Evidence from Selected Stocks in The Manufacturing Sector.International Journalof Financial Research. 5(1).

Aditya, I Gusti Ngurah Wira; Badjra, Ida Bagus. (2018). Peran Profitabilitas dalam Memediasi Pengaruh Tingkat Suku Bunga dan Leverage Terhadap Return Saham. Jurnal Manajemen Unud. 7(4). 1831-1861

Aga, Bahram Shadkam; Mogaddam, Vahid Farzin; Samadiyan, Behnam. (2013). Relationship between liquidity and stock returns in companies in Tehran Stock Exchange. Applied mathematics in Engineering, Management and Technology. Vol. 4. Pp 278-285.

Akoto, R.K; Awunyo-Vitor, D.; \& Angmor, P.L. (2013). Working capital management and profitability: Evidence from Ghanaian listed manufacturing firms. Journal of Economics and International Finance, 5(9), 373-379.

Alozzi, Nurah Musa; Obiedat, Ghassan S. (2016). The Relationship Between the Stock Return and Financial Indicators (Profitability, Leverage): An Empirical Study on Mnufacturing Companies Listed in Amman Stock Exchange. Journal of Social Sciences, Vol. 15 Pp 408-424.

Anwaar, Maryyam. (2016). Impact of Firms Performance on Stock Returns: Evidence from Listed Companies of LTSE-100 Index London, $U K$. Global. Journal of Management and Business Research. 16(1). 
Arista, Belananda Dwi; Topowijono. (2017). Pengaruh Struktur Modal Terhadap Profitabilitas (Studi Pada Perusahaan Sub Sektor Otomotif dan Komponen yang Terdaftar di Bursa Efek Indonesia Periode (2013)(2015)). Jurnal Administrasi Bisnis. 46(1)

Ariyanti, Ajeng Ika. (2016). Pengaruh Current Ratio, Tato, Net Profit Margin dan Return On Assets terhadap Return Saham. Jurnal Ilmu dan Riset Manajemen. 5(4)

Astuti, Pudji. (2017). The Influences of Fundamental Factors and Systematic Risk to Stock Prices on Companies Listed in the Indonesian Stock Exchange. European Research Studies Journal. Vol. 20. Pp 230-240.

Banerjee, Sanbad; Bandyopadhyay, Gautam. (2016). A Post Factor Analysis of Financial Ratios of Selected IPOs and its Impact on Grading: An Empirical Inquest. Journal of Business Studies Quarterly. Vol. 8 Pp 2334.

Boutilda, Riris. (2015). Analisis Pengaruh Struktur Modal Terhadap Profitabilitas Perusahaan (Studi Empiris Perusahaan-Perusahaan Manufaktur yang Terdaftar di BEI Periode 2009-(2013))." Jurnal Fakultas Ekonomi UI (2015).

Candrawati, Ni Putu Juni. (2017). Analisis Pengaruh Likuiditas dan Aktivitas Terhadap Profitabilitas Perusahaan Makanan dan Minuman Yang Terdaftar di Bursa Efek Indonesia Periose (2010)-(2014). Skripsi Universitas Lampung.

Fahmi, Irham. (2014). Analisis Kinerja Keuangan. Bandung: Alfabeta

Fitriyani, Rizka. (2013). Pengaruh Likuiditas Terhadap Profitabilitas. Skripsi Universitas Pendidikan Indonesia.

Frederick, O; Muiva, B. N. (2015). Fudamental Analysis of Stock Returns of Non-Financial Firms Listed at The Nairobi Securities Exchange. Universal Journal of Accounting and Finance. 3(3). 113-116

Gill, Amarjit; Biger, Nahum; Mathur, Neil. (2011). The Effect of Capital Structure on Profitability: Evidence from the United States. International Journal of Management. 28(4).

Hartono, Jogiyanto. (2015). Teori Portofolio dan Analisis Investasi. Yogyakarta:BPFE

Husnan, Suad. (2000). Manajemen Keuangan Teori dan Penerapan, Edisi Ketiga. Yogyakarta : UPP AMP YKPN

Husnan, Suad; Pudjiastuti, Enny. (2012). Dasar - Dasar Manajemen Keuangan. Edisi Keenam Cetakan Pertama. Yogyakarta: UPP STIM YPKN.

Ibrahim, Idris; Bala, Hussaini. (2017). Firms Specific Characteristics and Stock Market Returns (Evidence From Listed Food and Baverages Firms In 
Nigeria. International Journal of Information, Business and Management. Vol. 9Pp 257-276.

Iqbal, N; Khattak, S. R; Khattak, M. A. (2013). Does fundamental analysis predict stock returns? evidence from non-financial companies listed on KSE. Knowledge Horizons Economics, 5(4), 182-190.

Kasmir. (2012). Analisis Laporan Keuangan. Jakarta : PT. Raja Grafindo Persada.

Kurniawan, Teddy; Yuliasi; Ghasarma, Reza. (2016). Pengaruh Likuiditas, Financial Leverage, Aktivitas Terhadap Return Saham dengan Profitabilitas SebagaI Variabel Mediasi. Jurnal Manajemen dan Bisnis Sriwijaya. 14(1).

Lindayani, Ni Wayan; Dewi, Sayu Ketut Sutrisna. (2016). Dampak Struktur Modal Dan Inflasi Terhadap Profitabilitas dan Return Saham Perusahaan Keuangan Sektor Perbankan. Jurnal Manajemen Unud. 5(8).

Mariana, Ni Luh Lina; Yudiaatmaja, Fridayana; Yulianthini, Ni Nyoman. (2016). Pengaruh Profitabilitas dan Leverage Terhadap Return Saham. Jurnal Bisma Universitas Pendidikan Ganesha. Vol. 4.

Munawir, S. 2004. Analisis Laporan Keuangan, Penerbit Liberty. Yogyakarta.

Nandani, I Gusti Ayu Ika Yuni; Sudjarni, Luh Komang. (2017). Pengaruh Likuiditas, Profitabilitas dan NilaI Pasar Terhadap Return Saham Perusahaan F \& B di BEI. Jurnal Manajemen Unud. 6(8). 4481-4509.

Parwati, R. R. Ayu Dika; Sudiartha, Gede Mertha. (2016). Pengaruh Profitabilitas, Leverage, Likuiditas, dan Penilaian Pasar Terhadap Retrun Saham pada Perusahaan Manufaktur. Jurnal Manajemen Unud. 5(1). 385-413.

Purba, Ida Bagus Gde Indra Wedhana; Yadnya, Putu. (2015). Pengaruh Ukuran Perusahaan dan Leverage Terhadap Profitabilitas dan Pengungkapan Corporate Social Responsibility.Jurnal Manajemen Unud. 4(8). 24282443

Putra, I Made Gunartha Dwi; Dana, I Made. (2016). Pengaruh Profitabilitas, Leverage, Likuiditas dan Ukuran Perusahaan Terhadap ReturnSaham Perusahaan Farmasi di BEI. Jurnal Manajemen Unud. 5(11)

Rahmawati, Nita. (2012). Pengaruh Likuiditas Terhadap Profitabilitas pada Perusahaan Telekomunikasi yang Go Public di BEI Periode 2006-2011. Skripsi Universitas Islam Negeri Maulana Malik Ibrahim. Malang.

Rehman, Mohammed Ziaur; Khan, Muhammad Nauman; Khokhar, Imran. (2015). Investigating Liquidity-Profitability Relationship: Evidence from Companies Listed in Saudi Stock Exchange (Tadawul). Journal of Applied Finance \& Banking. 5(3). 159-173.

Riyanto, Bambang. (2001). Dasar-dasar Pembelanjaan Perusahaan. Edisi 4 Cetakan Ketujuh. BPFE UGM. Yogyakarta. 
Safdar, Muhammad Zulqarnain; Awan, Muhammad Zahid; Ahamed, Zeeshan; Qureshi, Muhammad Imran; Hasnain, Tafakhar. (2016). What Does Matter? Liquidity or Profitability: A Case of Sugar Industry in Pakistan. International Journal of Economics and Financial Issues. 6(S2). 1444152.

Sanjaya, I Dewa Gede Gina; Sudirman, I Made Surya Negara; Dewi, M. Rusmala. (2015). Pengaruh Likuiditas dan Aktivitas Terhadap Profitabilitas pada PT PLN (PERSERO). Jurnal Manajemen Unud. 4(8).

Sari, Ni Made Sri Kristina; Badjra, Ida Bagus. (2016). Pengaruh Likuiditas, Ukuran Perusahaan, Leverage dan Jaminan Terhadap Peringkat Obligasi pada Sektor Keuangan. Jurnal Manajemen Unud. 5(8). 5041-5069

Sartono, Agus. (2000). Manajemen Keuangan, Teori dan Aplikasi. Edisi Kedua. Yogyakarta: BPFE UGM.

Singapurwoko, Arif; Muhammad, Shalahuddin Mustofa El-Wahid. 2011. The Impact of Financial Leverage to Profitability Study of Non-Financial Companies Listed in Indonesia Stock Exchange. European Journal of Economics, Finance and Administrative Sciences, h: 137-148: Issue 32: ISSN 1450-2275

Sudarman, La. (2017). Peran Rasio Profitabilitas dalam Memediasi Pengaruh Rasio Rasio Likuiditas dan Solvabilitas Terhadap Return Saham. Jurnal Analisa Analisa Akuntansi dan Perpajakan. 1(2)

Sudaryo, Yoyo; Sari, Mila Novita. (2015). Pengaruh Debt to Equity Ratio (DER) Terhadap Return on Asset (ROA) pada Perusahaan Manufaktur Sektor Farmasi yang Terdaftar di Bursa Efek Indonesia (BEI) Periode 2008(2012). Jurnal STIE INABA. 14(2).

Sugiarti; Surachman; Aisjah, Siti. (2015). Pengaruh Kinerja Keuangan Perusahaan terhadap Return Saham (Studi pada Perusahaan Manufaktur yang Terdaftar di Bursa Efek Indonesia). Jurnal Aplikasi Manajemen. 13(2).

Tandelilin, Eduardus. (2010). Portofolio dan Investasi Teori dan Aplikasi. Edisi pertama. Yogyakarta :Kanisius

Tandelilin, Eduardus. (2012). Analisis Investasi dan Manajemen Portofolio Teori dan Aplikasi. Yogyakarta: BPFE.

Varghese, Titto; Dhote, Kamal Kishore. (2014). Impact of Working Capital Management on Firm Profitability: A Case Study of HUL Ltd., India. International Journal of Financial Management. 4(4).

Violita, Resi Yanuesti; Sulasmiyati, Sri. (2017) Pengaruh Struktur Modal Terhadap Profitabilitas (Studi Pada Perusahaan Food and Baverages Yang Terdaftar di BEI Tahun (2013)-(2016)) . Jurnal Administrasi Bisnis. 51(1). 
E-Jurnal Manajemen, Vol. 8, No. 6, $2019: 3303-3332$

Wiagustini, Ni luh Putu. (2010). Dasar-Dasar Manajemen Keuangan. Denpasar. Udayana University Press.

Wiagustini, Ni luh Putu. (2014). Dasar-Dasar Manajemen Keuangan. Denpasar. Udayana University Press.

Widiyanti, Marlina; Elfina, Friska Dwi. (2015). Pengaruh Financial Leverage Terhadap Profitabilitas pada Perusahaan Sub Sektor Otomotif dan Komponen yang Terdaftar di Bursa Efek indonesia. Jurnal Manajemen dan Bisnis Brawijaya. 13(1).

Yulia. (2016). Analisis Pengaruh Rasio Likuiditas Terhadap Return Saham (Studi Pada Perusahaan Indeks LQ 45 Yang Terdaftar Di Bursa Efek Indonesia). Jurnal Khatulistiwa Informatika. 4(2)

Zahro, Nafi Inayati. (2012). Pengaruh Rasio Profitabilitas Terhadap Return Saham Perusahaan Manufaktur Yang Terdaftar di Bursa Efek Indonesia. Jurnal Sosial Budaya. 5(1). 